\title{
Què en pensa l'alumnat d'educació secundària obligatòria amb baix rendiment acadèmic del seu ensenyament?
}

\section{Entitat que financia: Fundació Propedagògic.}

\section{Duració: 2011-2013 (3 anys)}

Hi ha alumnes escolaritzats en Educació Secundària Obligatòria (ESO) amb un baix rendiment acadèmic accentuat per un grau elevat de desmotivació, amb un alt risc de fracàs escolar.Per fracàs escolar s'entén normalment el fet de no aconseguir el títol acadèmic obligatori al finalitzar I' Educació Secundària Obligatòria (ESO). Així, un alumne fracassa en el sistema educatiu quan no és capaç d'assolir el nivell de rendiment mig esperat per la seva edat. Aquest es produeix quan falla algun aspecte del sistema educatiu, és a dir, fracassa alguna acció educativa que no ha estat orientada correctament. Podria definir-se com un desajustament entre el procés d'ensenyança proposat i el de l'aprenentatge de l'alumne/a. El problema de baix rendiment $i$ fracàs escolar a les nostres aules és una qüestió força important ja que segons dades actuals quatre de cada deu alumnes (cinc si són nois) arriben a l'últim any de l'educació obligatòria (4t curs d'ESO) amb més de 16 anys, l'edat idònia per fer aquest curs. Això significa que han repetit ja alguna vegada i entre aquests, el 35\% comença a despenjar-se a Primària, mentre que el $65 \%$ comença a repetir a Secundària (La MALLA. 14.12.09).

Aquest alumnat amb baix rendiment escolar necessita una oferta educativa alternativa, com són les aules obertes que permeten millorar l'èxit en alumnes d'alt risc de fracàs, prevenció de riscos socials ( inadaptació i marginació socials), disminució del tant per cent d'absentisme escolar, promoure l'adquisició d'habilitats socials, competències bàsiques,... tot per tal de contribuir a millorar la seva autoestima.

Les aules obertes són entorns escolars innovadors i flexibles, una forma organitzativa i metodològica dels programes de diversificació curricular. Aquests programes tenen com a finalitat afavorir que l'alumnat que ho requereixi pugui assolir els objectius i les competències bàsiques de l'etapa i obtenir el títol de graduat en educació secundària 
obligatòria, mitjançant una organització de continguts i matèries del currículum diferent a l'establert amb caràcter general i una metodologia específica i personalitzada.

En aquesta investigació es vol donar la veu i protagonisme a aquest alumnat que moltes vegades no es prou considerat. Es pretén conèixer quin és el seu pensament sobre la seva educació per tal de millorar l'atenció educativa en aquests espais educatius, les aules obertes, $i$ en les aules ordinàries i apuntar quines són les millors actuacions de tipus organitzatiu, metodològic i curriculars per a aconseguir-ho.

Té com a objectius generals:

- Identificar i difondre els aspectes metodològics, curriculars i organitzatius que l'alumnat amb dificultats escolars d'ensenyament secundari obligatori, considera més adients per a millorar el seu procés d'ensenyamentaprenentatge.

- Fer propostes de millora en l'actuació del professorat que atén a aquest alumnat

I com a objectius específics

- Conèixer les necessitats en què s'ha trobat l'alumnat amb baix rendiment per poder realitzar els seus estudis.

- Conèixer quins aspectes els hi resulten més profitosos per aprendre eficaçment en els àmbits:

- curriculars

- metodològics

○ organitzatius

- Conèixer quins aspectes els hi ha resultat més negatius en els àmbits abans esmentats.

- Conèixer el grau de satisfacció i acceptació de la seva estada en una aula oberta.

- Conèixer quines demandes farien al professorat per tal de millorar el seu procés d'ensenyament-aprenentatge.

A grans trets, el procés i els plantejaments generals que es segueixen per a portar a terme aquesta investigació, són els següents:

a) Primera aproximació al tema d'estudi i determinació dels objectius. Per aconseguir-ho, ens servirem de: la bibliografia sobre el tema, de l'assistència a congressos i/o jornades $\mathrm{i}$ dels contactes personals amb 
professors tutors, psicopedagogs i equips d'atenció psicopedagògica (EAP)i alumnes amb baix rendiment acadèmic.

b) Fonamentació teòrica de la investigació. Per la qual cosa estudiarem a través de la literatura, els camps següents:

- L'atenció educativa a la diversitat.

- Atenció a l'alumnat amb necessitats educatives.

- Mesures d'atenció a la diversitat a secundària.

- Aspectes metodològics i organitzatius per atendre la diversitat i les necessitats educatives.

- Les aules obertes.

- Causes del fracàs escolar i de baix rendiment.

c) Elaboració i passi d'un qüestionari sobre el pensament de l'alumnat amb baix rendiment acadèmic envers la seva educació.

d) Elecció d'una mostra representativa de l'alumnat amb baix rendiment acadèmic i realització d'entrevistes per a l'aprofundiment de les qüestions capitals tractades al qüestionari.

e) Recollida de les dades facilitades fonamentalment per l'alumnat enquestat.

f) Estudi de les dades. Conclusions i discussió.

g) Elaboració de la memòria final

\section{Bibliografia}

BISQUERRA, R (Coord) (1998): Modelos de orientación e intervención psicopedagógica. Barcelona.

DECRET 143/2007, de 26 de juny, pel qual s'estableix l'ordenació dels ensenyaments de l'educació secundària obligatòria (DOGC núm. 4915, 29.6.2007)

FERNÁNDEZ SIERRA, J (Coord) (1995): El trabajo docente y psicopedagógico en la educación secundaria. Aljibe. Málaga.

FERNÁNDEZ SIERRA, J (Coord) (1999) Acción psicopedagógica en educación secundaria. Málaga. Aljibe.

GARCIA, MORENO, TORREGO (1996): Orientación y tutoría en la Educación secundaria. Aljibe. Málaga.

GUTIÉRREZ ASCANIO, C. (2004). La deserción de los estudiantes: un estudio exploratorio en la ULPGC (Vol. 1). Las Palmas de Gran Canaria: Universidad de Las Palmas de Gran Canaria, Vicerrectorado de planificación y calidad. 
MARCHESI, A. (2003). El fracaso escolar en España (Vol. 11-2003). Madrid: Fundación Alternativas.

MARCHESI, A. (2004). Que será de nosotros, los malos alumnos (Vol. 255). Madrid: Alianza.

MARTÍN JIMÉNEZ, A. (2003). El fracaso escolar: una perspectiva internacional. Madrid: Alianza.

MARTÍNEZ, J.S (2004): Fracaso Escolar, PISA y la difícil ESO . Revista de la Asociación de Sociología de la Educación. Vol.2 nº1 enero 2009

MONEREO, C (Coord) (1996): Orientació educativa i intervenció psicopedagógica. Barcelona. UOC.

MONEREO, C, SOLE,I (Coord) (2001): El asesoramiento psicopedagógico: una perspectiva profesional y constructivista. Madrid. Ed. Alianza Editorial.

NIETO,J.M; BOTÍAS, F (2000): Los equipos de orientación educativa y psicopedagógica. El asesoramiento a centros escolares desde un análisi institucional. Barcelona. Ariel.

OCDE (2003). Resumen de Resultados PISA 2003.Programa para la Evaluación Internacional de los Alumnos (PISA). Madrid: Ministerio de Educación y Ciencia INECSE.

RESOLUCIÓ de 29 de maig de 2009 relativa a I'organització i el funcionament dels centres públics d'educació secundària per al curs 2009-2010. Generalitat de Catalunya.

\section{Investigadors}

Gabriel Comes, professor Titular de l'àrea de Didàctica i Organització escolar del Departament de Pedagogia de la Universitat Rovira i Virgili de Tarragona. Correu electrònic de contacte: gabriel.comes@urv.cat

Belén Parera, professora becaria predoctoral de l'àrea de Didàctica i Organització escolar del Departament de Pedagogia de la Universitat Rovira i Virgili de Tarragona. Correu electrònic de contacte: belen.parera@urv.cat

Gemma Vedriel, professora Associada de l'àrea de Didàctica i Organització escolar del Departament de Pedagogia de la Universitat Rovira i Virgili de Tarragona. Correu electrònic de contacte: gemma.vedriel@urv.cat

Maria Vives, professora Ajudant de l'àrea de Didàctica i Organització escolar del Departament de Pedagogia de la Universitat Rovira i Virgili de Tarragona. Correu electrònic de contacte: maria.vives@urv.cat 